Bangl. J. Vet. Med. (2013). 11 (2): 93-95

ISSN: 1729-7893 (Print) 2308-0922 (Online)

\title{
THE EFFICACY OF TURMERIC EXTRACT AGAINST EXPERIMENTALLY INDUCED Eimeria Maxima INFECTION IN BROILER
}

\author{
A. A. Candra* and D. D. Putri \\ Department of Animal Husbandary, State Politechnic of Lampung, \\ Soekarno Hatta, Street No 1, Rajabasa Bandar Lampung
}

\begin{abstract}
Broiler is one of the important sources of animal protein. Various feed additives are given to broiler to increase growth in a very short time. However, several diseases cause severe reduction in the rate of growth in chicken. One of those diseases is coccidiosis responsible for immunosuppression in the host. With the property of anti-diarrhea and anti-inflammatory, turmeric is expected to be an alternative for the treatment and prevention of coccidiosis in particular and general gastrointestinal disease in chickens. The purpose of this study was to determine the efficacy of turmeric extract agianst experimentally induced Eimeria maxima infection in broiler. The results showed that administration of turmeric extract with ethanol increases body weight gain, feed efficiency and also reduce mortality.
\end{abstract}

Key words: Performance, broiler, Eimeria maxima, turmeric

\section{INTRODUCTION}

Broiler chickens have been developed as a source of animal protein needs. Broiler is the term given to the technology of cultured chicken strains that have economic characteristics, with the rapid growth as a producer of meat, efficient feed conversion, and ready to be sold in relatively young age, and produce quality meat (Murtidjo, 1987).

Temulawak (Curcuma xanthorrhiza Roxb) is a common and nutritious crop that is empirically believed to be used as relatively safe drug and without leaving residue in the final product. Several reports on the use of turmeric as a treatment has been widely reported, such as antibacterial, lowering cholesterol levels, pain relief, antiinflammation, and lower the heat disease and often the skin problem (Yuniusta et al., 2007). In addition, it is also useful to prevent liver disease and as diuretic. Turmeric can be used to reduce diseases/conditions like hepatitis, gallstones, stomach ulcers, nephritis, asthma, ulcers, eczema, constipation, thrush, dismenorrhea, cough, diarrhea and inflammation (Ozaki, 1990).

Chickens infected with coccidiosis show signs of diarrhea, emaciation and mucosal damage simultaneously, thus reducing the rate of growth of chickens. With the ability of anti-diarrhea and anti-inflammatory turmeric is expected to be an alternative for the treatment and prevention of coccidiosis in particular and general gastrointestinal disease in chickens. The purpose of this study was to determine the performance of ginger and turmeric extract to the broiler experimentally infected by Eimeria maxima.

\section{MATERIALS AND METHODS}

This research was conducted at the laboratory of livestock in Lampung State Polytechnic during March to August, 2013. Materials used include: 60 broiler chickens of two weeks age, chicken rations, drinking water, turmeric (dried or extract with water and ethanol solvent). Sixty-day old chick (DOC) strain CP 707 with the male sex, were placed in cages measuring 4 meters x 2 meters dividing into 12 plots, each plot size $100 \mathrm{~cm} \mathrm{x} 50 \mathrm{~cm} \mathrm{x}$ $60 \mathrm{~cm}$, and 5 DOC per plot. To evaluate the efficacy of turmeric extract 3 plots were allocated for each treatment and control. On day 14, all chickens were infected with Eimeria maxima artificially by gastric tube. The experimentally infected broilers were treated with turmeric extract water solvent (P1) and ethanol extract of turmeric (P2) each $360 \mathrm{mg} / \mathrm{kg}$ body weight and just water as control from the 15 th to 35 day. Parameters measured were feed intake, body weight gain, feed efficiency, feed conversion, bile volume, and mortality. Data were analyzed with a completely randomized design and efficacy of the treatment was tested with LSD.

\footnotetext{
*Corresponding e-mail address: adicandra@polinela.ac.id 


\section{A. A. Candra and D. D. Putri}

\section{RESULTS}

The water and ethanol extract of turmeric showed noticeable difference in body weight gain (Table 1). The ethanol extract has relatively better effect than that extracted with water. Yuniusta et al. (2007) reported that turmeric helps the body's metabolic processes for the presence of curcuminoids and essential oils.

Broilers treated with ethanol extract of turmeric consumed lowest amount of feed, gained highest weight and produced more bile volume than broiler which treated with that of water extract. The mortality was also lowest in ethanol extract treated group (Table). Chickens infected with coccidiosis by Eimeria maxima showed signs of diarrhea, weight loss and mucosal damage, thus reducing the growth of chickens (Table 1).

Table 1. Efficacy of turmeric extract on feed consumption, weight gain, feed efficiency, bile production and mortality

\begin{tabular}{|lccc|}
\hline \multicolumn{1}{|c}{ Variable } & \multicolumn{2}{c|}{ Treatment } \\
\hline & Control & $\begin{array}{c}\text { Water } \\
\text { extract of turmeric }\end{array}$ & $\begin{array}{c}\text { Ethanol extract of } \\
\text { turmeric }\end{array}$ \\
\hline Consumption $(\mathrm{g})$ & $6.18 \pm 0.15$ & $6.08 \pm 0.15$ & $5.66 \pm 0.15$ \\
Body weight gain $(\mathrm{g})$ & $1420.8 \pm 315.1$ & $1531.75 \pm 350.8$ & $1693.25 \pm 367.7$ \\
Feed conversion & 4.35 & 3.97 & 3.34 \\
Feed efficiency $(\%)$ & 23 & 25 & 30 \\
Bile volume $(\mathrm{ml})$ & 0.48 & 0.5 & 0.9 \\
Mortality $(\%)$ & $10 \%$ & $5 \%$ & $2 \%$ \\
\hline
\end{tabular}

\section{DISCUSSION}

Darwis et al. (1991) reported that the curcuminoids have anti-bacterial properties and can stimulate the gall bladder wall to secrete bile that can accelerate fat metabolism. Bile is a greenish-yellow liquid salt containing cholesterol, phospholipid, lecithin and bile pigments. Bile salts contain a number of salts from the mixture of sodium and potassium with bile acids (taurocholic acid and glycocholic). These salts mix with the fat in the small intestine to form micelles, which reduces surface tension between the fat and help in fat digestion.

Frandson (1992) claimed that bile salts are alkaline and can assist in creating a more alkaline environment in the intestinal chyme. Bile salts help to neutralize the acidity of the intestinal contents in the duodenal curve, producing an alkaline state so as to reach the level of $\mathrm{pH}$ appropriate for digestibility.

Essential oils contained in turmeric also regulate gastric acid secretion that is not excessive (Darwis et al., 1991). Hydrochloric acid secreted from parietal cells helps to activate pepsinogen to pepsin, the enzyme responsible for protein digestion (Harper et al., 1980). Proper digestion of protein will lead to better protein metabolism in the body that will also affect the growth.

Frandson (1992) reported that the factors that control gastric emptying through the pyloric sphincter include the volume of food in the stomach, the fluidity of the mix, as well as duodenal receptivity.

The addition of ethanol extract of turmeric in feed can reduce the effect of immunosuppression as caused by Eimeria maxima infections. It may be a solution for the treatment of chickens that are experiencing stress.

\section{CONCLUSION}

Provision of turmeric extract with ethanol may increase body weight gain, feed efficiency and decrease mortality caused by Eimeria maxima infection.

\section{REFERENCES}

1. Darwis SN, Modjo Indo dan ABD and Hasiyah S (1991). Tanaman Obat Familia Zingiberaceae. Badan Penelitian dan Pengembangan Pertanian Industri, Bogor.

2. Frandson RD (1992). Anatomi dan Fisiologi. Alih Bahasa Bambang Srigandono dan Koen Praseno. Edisi keempat, Gadjah Mada University Press, Yogyakarta. 
3. Harper AH, Rodwell VW and Mayer PA (1980). Biokimia (Review of Physiological Chemistry). Alih Bahasa Martin Muliawan, Edisi ke-17, Penerbit Buku Kedokteran E. G. C. Jakarta.

4. Murtidjo BA (1987). Pedoman Beternak Ayam Broiler. Penerbit Kanisius. Yogyakarta.

5. Ozaki Y (1990). Antiinflamatory effec of Curcuma xanthorriza and its active Principles. Chemical and Pharmaceutical Bulletin 38: 1045-1048.

6. Yuniusta Syahrio T and Septinova D (2007). Perbandingan Performa Antara Broiler Yang Diberi Kunyit dan Temulawak melalui Air minum. Fak, Pertanian, University, Lampung. 